\title{
Pengaruh inokulasi Mikoriza Vesikular Arbuskula (MVA) dan pupuk pelengkap cair terhadap pertumbuhan, komponen hasil dan hasil tanaman kedelai pada tanah Inceptisols Jatinangor
}

\section{The effect of dosage of arbuscular vesicular mycorrhiza and liquid fertilizer complement on growth yield components and yield of soybean on Inceptisols Jatinangor}

\author{
Diterima : 17 Agustus 2017/Disetujui : 25 Agustus 2017 / Dipublikasikan : 31 Agustus 2017 \\ CDepartment of Crop Science, Padjadjaran University
}

\begin{abstract}
The objective of this research was to determine the interaction effect of Dosage of Arbuscular Vesicular Mycorrhiza and Liquid Fertilizer Complement on Growth, yield components and yield of soybean in inceptisols Jatinangor. The experiment was carried out from November 2015 until April 2016 at the research station of Agriculture Faculty of Padjadjaran University, Jatinangor.

The experimental design used a Randomized Block Design (RBD) factorial pattern and three replications. The treatments as the first factor were three levels of e Arbuskular Vesicular Micorrhiza dosage, $5 \mathrm{~g} /$ polybag, $10 \mathrm{~g} /$ polybag and 15 $\mathrm{g} /$ polybag; and as the second factor was three levels of concentration of liquid fertilizer complement" Pesat" trade mark, $10 \mathrm{cc} / \mathrm{L}, 15 \mathrm{cc} / \mathrm{L}$ and $20 \mathrm{cc} / \mathrm{L}$ with three polybags per plot, totally 81 polybags. Duncan test was used to compare means among treatments.

The result showed that there were no significant effect of interaction of dosage of arbuscular vesicular mycorrhiza and concentration of liquid fertilizer complement on component of growth, components of yield and yield. The application of $15 \mathrm{~g} /$ polybag arbuscular vesicular mycorrhiza and application $20 \mathrm{cc} / \mathrm{L}$ liquid fertilizer complement showed the highest effect on height of plant, leaf area index, number of productive lateral leaf, number of pertile, number of pods and empty pods, weight of 100 seeds, seed number per plant, weight seed per plot and harverst index. The highest yield is about $3.04 \mathrm{t} / \mathrm{ha}$.
\end{abstract}

\footnotetext{
Dikomunikasikan oleh Sosiawan Nusifera

Irwan, A.W. · A. Wahyudin

Staff Departemen Budidaya Pertanian Fakultas Pertanian

Universutas Padjadjaran

Korespondensi: aep_wawan_irwan@yahoo.co.id
}

Keywords : Soybean $\cdot$ AVM $\cdot$ Liquid fertilizer complement

Sari Percobaan ini bertujuan untuk mengetahui pengaruh interaksi antara pupuk organik cair dan MVA sehingga diketahui dinamika pengaruh faktor pada taraf pupuk pelengkap cair yang berbeda dari faktor MVA yang diberikan terhadap pertumbuhan dan hasil tanaman kedelai kultivar Kaba pada tanah inceptisols di Jatinangor. Percobaan dilaksanakan di Kebun Percobaan Fakultas Pertanian, Universitas Padjadjaran, Jatinangor, dari bulan November 2014 sampai April 2015.

Percobaan ini menggunakan metode dengan Rancangan Acak Kelompok (RAK) pola faktorial yang terdiri dari dua faktor, yaitu faktor pertama adalah dosis Mikoriza Vesikular Arbuskular (MVA), yaitu $5 \mathrm{~g} /$ polybag, $10 \mathrm{~g} /$ polybag dan 15 $\mathrm{g} /$ polybag dan faktor kedua yaitu dosis pupuk pelengkap cair (PPC) merk dagang "Pesat", yaitu $10 \mathrm{cc} / \mathrm{L}, 15 \mathrm{cc} / \mathrm{L}$ dan $20 \mathrm{cc} / \mathrm{L}$, dan dimana perlakuan tersebut diulang sebanyak tiga kali, sehingga diperoleh jumlah plot masing-masing unit percobaan adalah $3 \times 3 \times 3=27$ polybag, dan setiap plot percobaan dibuat tiga unit sehingga diperoleh 81 polybag. Untuk menguji beda hasil rata-rata perlakuan, dilakukan uji jarak berganda Duncan dengan taraf 5\%.

Hasil percobaan menunjukkan bahwa tidak ada pengaruh interaksi antara inokulasi mikoriza vasikular arbuskula dengan pupuk pelengkap cari terhadap pertumbuhan, komponen hasil dan hasil tanaman kedelai. Pemberian MVA $15 \mathrm{~g} /$ polybag memberikan pengaruh yang lebih baik terhadap tinggi tanaman, Indeks Luas Daun, Jumlah Cabang Produktif dan Jumlah Buku Subur, Jumlah Polong Isi dan Jumlah Polong Hampa per 
Tanaman, Bobot 100 butir, Bobot Biji per Tanaman dan Indeks Panen, sedangkan pemberian $20 \mathrm{cc} / \mathrm{L}$ pupuk pelengkap cair memberikan pengaruh yang lebih baik tinggi tanaman, Indeks Luas Daun, Jumlah Cabang Produktif dan Jumlah Buku Subur, Jumlah Polong Isi dan Jumlah Polong Hampa per Tanaman Bobot 100 butir, Bobot Biji per Tanaman dan Indeks Panen. Bobot biji per tanaman yang tertinggi sebesar $31,71 \mathrm{~g} /$ tanaman atau sekitar 3.04 ton/ha.

Kata kunci : Kedelai · MVA · Pupuk pelengkap cair

\section{Pendahuluan}

Kebutuhan kedelai di Indonesia setiap tahun selalu meningkat seiring dengan pertambahan penduduk dan perbaikan pendapatan perkapita. Oleh karena itu, diperlukan suplai kedelai tambahan yang harus diimpor karena produksi dalam negeri belum dapat mencukupi kebutuhan tersebut. Lahan budidaya kedelai pun diperluas dan produktivitasnya ditingkatkan. Untuk pencapaian usaha tersebut, diperlukan pengenalan mengenai tanaman kedelai yang lebih mendalam.

Komposisi kimia biji kedelai kering per 100 gram yakni 331,0 kkal kalori, 34,9 g protein, 18,1 g lemak, 34,8 g karbohidrat, 227,0 mg kalsium, $585,0 \mathrm{mg}$ fosfor, $8,0 \mathrm{mg}$ besi, 110,0 SI vit A, 1,1 $\mathrm{mg}$ vit $\mathrm{B}$, dan $7,5 \mathrm{~g}$ air. Di samping itu, kadar asam amino kedelai termasuk paling lengkap. Tiap satu gram asam amino kedelai mengandung $340 \mathrm{mg}$ Isoleusin, $480 \mathrm{mg}$ Leusin, $400 \mathrm{mg}$ Lisin, $310 \mathrm{mg}$ Fenilalanin, $200 \mathrm{mg}$ Tirosin, $80 \mathrm{mg}$ Metionin, $110 \mathrm{mg}$ Sistin, $250 \mathrm{mg}$ Treonin, $90 \mathrm{mg}$ Triptofan, dan 330 mg Valin (( Sumarno, 1987).

Di Indonesia, kedelai menjadi sumber gizi protein nabati utama, meskipun Indonesia harus mengimpor sebagian besar kebutuhan kedelai. Ini terjadi karena kebutuhan Indonesia yang tinggi akan kedelai putih. Kedelai putih bukan asli tanaman tropis sehingga hasilnya selalu lebih rendah daripada di Jepang dan Cina. Pemuliaan serta domestikasi belum berhasil sepenuhnya mengubah sifat fotosensitif kedelai putih. Di sisi lain, kedelai hitam yang tidak fotosensitif kurang mendapat perhatian dalam pemuliaan meskipun dari segi adaptasi lebih cocok bagi Indonesia.

Kedelai merupakan tumbuhan serbaguna. Karena akarnya memiliki bintil pengikat nitrogen bebas, kedelai merupakan tanaman dengan kadar protein tinggi sehingga tanamannya digunakan sebagai pupuk hijau dan pakan ternak. Pemanfaatan utama kedelai adalah dari biji. Biji kedelai kaya protein dan lemak serta beberapa bahan gizi penting lain, misalnya vitamin (asam fitat) dan lesitin. Biji kedelain dapat diolah antara lain menjadi tahu (tofu), tempe, taosi, tauco, tepung kedelai, bermacam-macam saus penyedap (salah satunya kecap, yang aslinya dibuat dari kedelai hitam), susu kedelai (baik bagi orang yang sensitif laktosa), minyak (dibuat sabun, plastik, kosmetik, resin, tinta, krayon, pelarut, dan biodiesel).

Produktivitas rata-rata kedelai nasional masih rendah, tahun sejak 2007 mencapai 13,07 $\mathrm{ku} / \mathrm{ha}$ atau 1,3 ton/ha. Potensi hasil ditingkat penelitian dan percobaan mencapai 2 ton atau lebih Senjang hasil masih tinggi antar ditingkat petani dan penelitian, sedangkan angka konsumsi kedelai dalam negeri cukup besar. Kebutuhan kedelai tahun 2012 mencapai 1,2 juta ton. Berdasarkan Badan Pusat Statistik, luas tanaman pangan non-beras Indonesia periode tahun 1995-2014 terus menurun. Luas panen kedelai turun dari 1,48 juta ha menjadi 728.200 ha. Hal tersebut disebabkan oleh keterbatasan lahan yang tersedia untuk budidaya pangan non-beras, khususnya kedelai. Untuk memenuhi kebutuhan dalam negeri, Indonesia masih harus terus melakukan impor yang rata-rata sebesar $40 \%$ dari kebutuhan kedelai nasional meningkat dari tahun ke tahun, produksi dalam negeri masih relatif rendah dan memiliki kecenderungan terus menurun. Hal ini menyebabkan ketergantungan akan kedelai impor terus berlangsung dan memiliki kecenderungan terus meningkat (BPS 2015).

Kedelai dibutuhkan untuk memenuhi kebutuhan protein murah bagi masyarakat dalam upaya meningkatkan kualitas SDM Indonesia Sejalan dengan pertambahan jumlah penduduk maka permintaan akan kedelai semakin meningkat. Pada tahun 1998 konsumsi per kapita baru $9 \mathrm{~kg} /$ tahun, kini naik menjadi 10 $\mathrm{kg} /$ th Dengan konsumsi perkapita rata-rata 10 $\mathrm{kg} /$ tahun maka dengan jumlah penduduk 220 juta dibutuhkan 2 juta ton lebih per tahun. Untuk itu diperlukan program khusus peningkatan produksi kedelai dalam negeri. Produksi kedelai pernah mencapai 1,86 juta pada tahun 1992 (tertinggi) kemudian turun terus hingga tahun 2014 hanya 0,8 juta ton. Kedelai mengalami penurunan produksi, disebabkan 
baik oleh kondisi curah hujan yang cukup tinggi dan kurangnya kepastian harga di tingkat petani sehingga petani kurang bergairah menanam kedelai.

Untuk mendorong peningkatan produksi kedelai sejak tahun 2008, akan dilaksanakan Program dan Aksi Peningkatan Produksi Kedelai Nasional Tahun 2008 dengan sasaran produksi 1.064 .000 ton dengan luas tanam 800.000 ha, luas panen 760.000 ha dan produktivitas rata-rata $14,00 \mathrm{~kg} / \mathrm{ha}$. Sasaran produksi kedelai tahun 2008 belum dicapai melalui strategi yaitu : Peningkatan Produktivitas, Perluasan Areal Tanam, Pengamanan Produksi dan Penguatan Kelembagaan dan Dukungan Pembiayaan, BPS 2015).

Salah satu upaya untuk meningkatkan produksi kedelai dapat ditempuh dengan pemberian pupuk. Di dalam tanah terutama tanah-tanah yang diusahakan secara intensif mempunyai kadar unsur hara esensial yang rendah, terutama unsur hara nitrogen $(\mathrm{N})$, sedangkan fosfor $(\mathrm{P})$, dan kalium $(\mathrm{K})$ yang cukup, namun belum tersedia bagi tanaman, sehingga perlu penambahan unsur hara melalui pemupukan (Darmawijaya, 1992). Untuk mengatasi masalah tersebut, perbaikan kesuburan tanah banyak dilakukan dengan jalan menambahkan bahan pupuk baik organik maupun anorganik yang bertujuan untuk meningkatkan produksi tanaman secara optimal.

Pemupukan yang biasa dan kebanyakan dilakukan petani hanya melalui tanah, sehingga unsur hara yang diberikan diserap oleh akar tanaman, kemudian ditransformasi menjadi bahan-bahan yang berguna bagi pertumbuhannya. Pemupukan melalui tanah tersebut kadang-kadang kurang bermanfaat, karena beberapa unsur hara telah larut lebih dahulu dan hilang bersama air perkolasi atau mengalami fiksasi oleh koloid tanah, sehingga tidak dapat diserap oleh tanaman.

Upaya yang dapat ditempuh agar pemupukan lebih efektif dan efisien adalah dengan menyemprotkan larutan pupuk melalui daun tanaman. Pemberian pupuk daun tersebut dapat memperbaiki pertumbuhan, mempercepat panen, memperpanjang masa atau umur produksi, dan dapat meningkatkan hasil tanaman (Bethlenfalvay, et al. 1991).

Setiap tahun ribuan hektar lahan yang subur berkurang akibat penggunaan pupuk kimia. Sungguh ironis, menggunakan racun untuk meningkatkan produksi pangan bagi kehidupan. Tidak heran bila kesehatan dan daya tahan tubuh manusia terus merosot. Sebaliknya Penggunaan pupuk organik tidak meninggalkan residu yang membahayakan bagi kehidupan. Pengaplikasiannya mampu memperkaya sekaligus mengembalikan ketersediaan unsur hara bagi tanah dan tumbuhan dengan aman.

Kemudian dihapusnya pupuk oleh pemerintah menimbulkan masalah mengenai pembiayaan dalam pengadaan pupuk SP. Mahalnya harga pupuk SP menyebabkan perhatian beralih pada penggunaan pupuk batuan fosfat (BP). Meskipun pupuk batuan fosfat (BP) lambat tersedia. Sehingga penggunaan pupuk hayati yang bertumpu pada penggunaan organisme tanah yang ramah lingkungan juga banyak mendapat perhatian (Sharma et al., 2004). Salah satu jamur yang dapat digunakan dan efektif dalam memenuhi kebutuhan unsur hara bagi tanaman adalah mikoriza.

Selain itu, untuk meningkatkan produktivitas tanah dan meningkatkan pertumbuhan tanaman diperlukan masukan dalam bentuk pupuk anorganik yang harus disertai dengan pupuk organik. Oleh karena itu, perlu dicari alternatif yang dapat menghasilkan produk yang diterima konsumen, ramah lingkungan dan untuk mengatasi kendala tanah masam. seperti pemanfaatan cendawan mikoriza arbuskular vasikular (MVA).

Mikoriza merupakan suatu bentuk simbiosis mutualistik antara jamur dan akar tanaman (Brundrett, et al 1996). Struktur yang terbentuk dari asosiasi ini tersusun secara beraturan dan memperlihatkan spektrum yang sangat luas, baik dalam hal tanaman inang, jenis cendawan maupun penyebarannya (Schinner et al., 1996). Umumya mikoriza dibedakan dalam tiga kelompok, yaitu: endomikoriza (pada jenis tanaman pertanian), ektomikoriza (pada jenis tanaman kehutanan), dan ektendomikoriza (Harley and Smith, 1983). Setiadi (2003), menyebutkan bahwa mikoriza juga sangat berperan dalam meningkatkan toleransi tanaman terhadap kondisi lahan kritis, yang berupa kekeringan dan banyak terdapatnya logam-logam berat sehingga dapat meningkatkan penyerapan jumlah $P$ yang tersedia bagi tanaman, sedangkan pupuk cair menyediakan nitrogen dan unsur mineral lainnya yang dibutuhkan untuk pertumbuhan tanaman.

Penelitian ini bertujuan untuk mengetahui pengaruh interaksi antara pemberian MVA dan PPC terhadap pertumbuhan dan hasil kedelai 
(Glycine max (L.) Merr.) pada tanah Inceptisols Jatinangor. Penelitian ini diharapkan dapat memberikan informasi yang bermanfaat bagi petani maupun pengusaha di bidang pangan, khususnya kedelai sehingga dapat meningkatkan produktivitasnya.

\section{Bahan dan Metode}

Penelitian ini dilaksanakan di Kebun Percobaan Fakultas Pertanian Universitas Padjadjaran Jatinangor Kabupaten Sumedang, Jawa Barat, ketinggian tempat sekitar $750 \mathrm{~m} \mathrm{dpl}$, dengan tipe $\mathrm{D}_{3}$ menurut klasifikasi Oldeman (1975). Jenis tanah inceptisol dengan $\mathrm{pH}$ tanah 5,6 (masam) dari bulan November 2014 sampai dengan April Benih kedelai yang ditanam adalah kultivar Kaba berasal dari BALITKABI Malang, Jawa Timur, hasil panen Oktober 2014, umur panen 90 hari setelah tanam, bobot 100 biji sebesar 10,37 gram. Pupuk yang digunakan terdiri atas pupuk dasar (Urea, SP-36 dan $\mathrm{KCl}$ ), dan pupuk pelengkap cair (PPC) yang digunakan adalah PESAT (merk dagang), mengandung unsur makro antara lain $\mathrm{N}, \mathrm{P}, \mathrm{K}$, $\mathrm{Ca}$ dan unsur mikro antara lain $\mathrm{Cu}, \mathrm{Mo}$.

Pemberian pupuk dasar dengan cara ditugal, sedangkan pemberian pupuk pelengkap cair dilakukan dengan cara menyiramkannya ke tanah sekitar perakaran, waktu aplikasi 2, 4, dan 6 MST.

Ukuran polybag dengan kapasitas tanah sebesar $10 \mathrm{~kg}$, tanah sebelumnya diayak dan digemburkan, lalu diberian pupuk kandang dengan dosis 5 ton/ha Jarak tanam yang digunakan untuk penanaman kedelai yaitu $25 \mathrm{x}$ $25 \mathrm{~cm}$ (jarak polybag antar perlakuan).

Percobaan ini menggunakan metode dengan Rancangan Acak Kelompok (RAK) pola faktorial yang terdiri dari dua faktor, yaitu faktor pertama yaitu dosis pupuk pelengkap cair (PPC) merk dagang "Pesat", yaitu $10 \mathrm{cc} / \mathrm{L}, 15$ $\mathrm{cc} / \mathrm{L}$ dan $20 \mathrm{cc} / \mathrm{L}$, dan faktor kedua adalah dosis Mikoriza Vesikular Arbuskular (MVA), yaitu 5 g/polybag, $10 \mathrm{~g} /$ polybag dan $15 \mathrm{~g} /$ polybag dimana perlakuan tersebut diulang sebanyak tiga kali, sehingga diperoleh jumlah plot masing-masing unit percobaan adalah $3 \times 3 \times 3=$ 27 polybag, dan setiap plot percobaan dibuat tiga unit sehingga diperoleh 81 polybag. Untuk menguji beda hasil rata-rata perlakuan, dilakukan uji jarak berganda Duncan dengan taraf $5 \%$.
Pengamatan dilakukan terhadap lingkungan tumbuh dan organisme pengganggu sebagai pengamatan penunjang dan pengamatan utama terdiri dari tinggi tanaman, jumlah cabang produktif, indeks luas daun, jumlah nodula akar efektif, derajat infeksi akar, bobot kering tanaman, jumlah polong isi dan jumlah polong hampa per tanaman, bobot 100 butir, bobot biji per tanaman dan indeks panen.

\section{Hasil dan Pembahasan}

Lingkungan Tumbuh dan Organisme Pengganggu. Hama yang menyerang tanaman, yaitu belalang (Valanga nigricornis). Belalang menyerang tanaman terutama saat tanaman masih muda sehingga nengakibatkan daun menjadi robek dan berlubang, tetapi percobaan di lapangan mnenunjukkan tingkat serangan belalang tidak sampai menimbulkan kerusakan yang signifikan, sekitar 5-10\%. Pengendalian dengan melakukan penyemprotan Curacron 500 EC dengan konsentrasi $2 \mathrm{ml} / 1$ air (saat terjadi serangan) yaitu pada $5 \mathrm{mst}$ dan $8 \mathrm{mst}$ (fase kritis).

Jenis penyakit yang menyerang adalah bercak daun (Cercospora rachidicola). Gejala serangannya yaitu permukaan atas maupun bawah daun berwarna coklat. Tanaman yang terserang penyakit sebesar $2 \%$ dan dapat diatasi dengan penyemprotan Dithane M-45 dengan konsentrasi $2 \mathrm{~g} / \mathrm{L}$ (4 mst sampai 12 mst dengan interval waktu satu minggu sekali).

Gulma yang tumbuh dominan pada lahan tempat percobaan yaitu teki (Cyperus rotundus), putri malu (Mimosa pudica), dan kakawatan (Cynodon dactilon). Pengendalian gulma dilakukan secara mekanik menggunakan kored.

Berdasarkan hasil analisis tanah diketahui bahwa jenis tanah tempat percobaan termasuk jenis tanah inceptisols. Tanah tersebut memiliki tekstur liat berdebu dengan komposisi $16 \%$ pasir, $40 \%$ debu, dan $44 \%$ liat. Nilai $\mathrm{pH}$ yang terukur dari tanah tersebut adalah 5.6 (masam), $\mathrm{pH}$ yang baik untuk pertumbuhan kedelai adalah 6-6,5 (Sumarno, 2011). Berdasarkan perbandingan kadar Corganik $(2,94 \%)$ dan $\mathrm{N}$-total $(0,25 \%)$, tanah tersebut memiliki nilai $\mathrm{C} / \mathrm{N}$ ratio sebesar 13 termasuk kriteria sedang, hal ini menunjukan bahwa tingkat dekomposisi bahan organik dalam tanah tersebut barada pada tingkatan sedang. Tanah tempat percobaan memiliki kandungan $\mathrm{P}_{2} \mathrm{O}_{5}$ tersedia (Bray) 9,2 ppm (rendah), $\mathrm{P}_{2} \mathrm{O}_{5}$ total ( $\mathrm{HC1}$ ) 
$22.4 \mathrm{mg} / 100 \mathrm{~g}$ (sedang), dan $\mathrm{K}_{2} \mathrm{O}$ (HC1) $20.1 \mathrm{mg} / 100$ g (sedang), kapasitas tukar kation 18.2 me/100g (sedang), kejenuhan basa $47 \%$ (rendah).

Data curah hujan selama penelitian berlangsung menunjukan bahwa curah hujan (bulan November 2015-April 2016) rata-rata pada bulan November $224.5 \mathrm{~mm}$ karena masih ada hujan, bulan Desember sebesar $145.8 \mathrm{~mm}$ dengan jumlah hari hujan 15 hari, bulan Januari $105.7 \mathrm{~mm}$ dengan jumlah hari hujan 12 hari, bulan Februari 146,7 mm dengan jumlah curah hujan 8 hari. Jumlah curah hujan ini relatif sesuai untuk tanaman kedelai yaitu 40 - $200 \mathrm{~mm} /$ bulan, untuk memenuhi kebutuhan air selama tidak turun hujan maka dilakukan penyiraman dengan interval waktu 2 kali sehari selama pertumbuhan vegetatif sampai memasuki fase reproduktif.

Tinggi Tanaman. Berdasarkan analisis data tinggi tanaman pada umur 3 MST, 5 MST dan 7 MST (Tabel 1), MVA dan pupuk pelengkap cair tidak memberikan pengaruh interaksi terhadap tinggi tanaman. Pada umur 3 MST, perlakuan MVA tidak menunjukkan pengaruh yang nyata, sedangkan pada 5 MST dan 7 MST pelakuan MVA memberikan pengaruh, dimana perlakuan $5 \mathrm{~g} /$ polybag memberingan pengaruh yang terbaik terhadap tinggi tanaman. Untuk perlakuan PPC, memberikan pengaruh yang nyata, semakin tinggi konsentrasinya maka semakin tinggi tanamannya; perlakuan terbaik yaitu pada perlakuan $20 \mathrm{cc} / \mathrm{L}$. Menurut Taiz dan Zeiger (2002), pada dasarnya pertumbuhan pada saat fase vegetatif pada tanaman muda lebih ke arah pembentukan daun muda dan pertumbuhan akar. Selain itu diduga tanaman yang masih muda terjadi kompetisi antara MVA dengan tanaman inang untuk mendapatkan fotosintat yang terbatas.

Indeks Luas Daun, Jumlah Cabang Produktif dan Jumlah Buku Subur. Berdasarkan analisis data ILD, jumlah cabang produktif dan jumlah buku subur MST (Tabel 2), MVA dan pupuk pelengkap cair tidak memberikan pengaruh interaksi terhadap tinggi tanaman. Secara mandiri, PPC dan MVA memberikan pengaruh yang nyata terhadap Indeks Luas Daun, jumlah cabang produktif dan jumlah buku subur dimana dosis MVA terbaik yaitu pada perlakuan $5 \mathrm{~g} /$ polybag, sedangkan perlakuan PPC, indeks luas daun $20 \mathrm{cc} / \mathrm{L}$ lebih baik dibandingkan dengan perlakuan PPC 10 cc/L dan 15 cc/L.
Tabel 1. Pengaruh Inokulasi Mikoriza Vesikular Arbuskula (MVA) dan Pupuk Pelengkap Cair terhadap Tinggi Tanaman.

\begin{tabular}{lccc}
\hline Perlakuan & \multicolumn{3}{c}{ Tinggi Tanaman $(\mathrm{cm})$} \\
& 3 MST & 5 MST & 7 MST \\
\hline MVA (M) & & & \\
$\mathrm{m}_{1}$ & $27.42 \mathrm{a}$ & $46.13 \mathrm{a}$ & $68.95 \mathrm{a}$ \\
$\mathrm{m}_{2}$ & $27.07 \mathrm{a}$ & $44.93 \mathrm{~b}$ & $67.90 \mathrm{a}$ \\
$\mathrm{m}_{3}$ & $27.74 \mathrm{a}$ & $44.39 \mathrm{~b}$ & $64.63 \mathrm{~b}$ \\
PPC (P) & & & \\
$\mathrm{p}_{1}$ & $26.45 \mathrm{a}$ & $45.72 \mathrm{a}$ & $66.45 \mathrm{a}$ \\
$\mathrm{p}_{2}$ & $26.96 \mathrm{a}$ & $45.87 \mathrm{a}$ & $66.82 \mathrm{a}$ \\
$\mathrm{p}_{3}$ & $27.21 \mathrm{~b}$ & $47.86 \mathrm{~b}$ & $68.21 \mathrm{~b}$ \\
\hline \hline
\end{tabular}

Keterangan : Nilai rata-rata perlakuan yang ditandai huruf yang sama pada kolom yang sama menunjukkan tidak berbeda nyata menurut Uji Jarak Berganda Duncan pada taraf $5 \%$.

Tabel 2. Pengaruh Inokulasi Mikoriza Vesikular Arbuskula (MVA) dan Pupuk Pelengkap Cair terhadap Indeks Luas Daun, Jumlah Cabang Produktif dan Jumlah Buku Subur per tanaman.

\begin{tabular}{lccc}
\hline \hline Perlakuan & ILD & $\begin{array}{c}\text { Jumlah } \\
\text { cabang } \\
\text { produktif }\end{array}$ & $\begin{array}{c}\text { Jumlah } \\
\text { buku } \\
\text { subur }\end{array}$ \\
\hline MVA (M) & $4.55 \mathrm{a}$ & $5.28 \mathrm{a}$ & $15.22 \mathrm{a}$ \\
$\mathrm{m}_{1}$ & $4.07 \mathrm{~b}$ & $3.88 \mathrm{~b}$ & $14.62 \mathrm{a}$ \\
$\mathrm{m}_{2}$ & $4.10 \mathrm{~b}$ & $4.05 \mathrm{~b}$ & $13.11 \mathrm{~b}$ \\
$\mathrm{~m}_{3}$ & & & \\
PPC (P) & $4.05 \mathrm{a}$ & $5.53 \mathrm{a}$ & $12.41 \mathrm{a}$ \\
$\mathrm{p}_{1}$ & $3.98 \mathrm{a}$ & $5.76 \mathrm{a}$ & $12.12 \mathrm{a}$ \\
$\mathrm{p}_{2}$ & $3.12 \mathrm{~b}$ & $6.12 \mathrm{~b}$ & $14.86 \mathrm{~b}$ \\
$\mathrm{p}_{3}$ & &
\end{tabular}

Keterangan : Nilai rata-rata perlakuan yang ditandai huruf yang sama pada kolom yang sama menunjukkan tidak berbeda nyata menurut $\mathrm{Uji}$ Jarak Berganda Duncan pada taraf $5 \%$.

Jumlah Nodul Akar Efektif, Derajat Infeksi Akar dan Bobot Kering per Tanaman. Berdasarkan analisis data statistik, jumlah nodul akar efektif, derajat infeksi akar dan bobot kering, perlakuan MVA dan pupuk pelengkap cair tidak memberikan pengaruh interaksi. Secara mandiri, jumlah nodul akar efektif, derajat infeksi akar dan bobot kering per tanaman memberikan pengaruh yang nyata, dimana dosis $5 \mathrm{~g} /$ polybag dan $10 \mathrm{~g} /$ polybag MVA berpengaruh lebih baik terhadap nodul akar efektif dibandingkan dengan $15 \mathrm{~g} /$ polybag, sedangkan perlakuan PPC, $20 \mathrm{cc} / \mathrm{L}$ memberikan jumlah nodul akar efektif terbaik dibandingkan dengan perlakuan PPC $10 \mathrm{cc} / \mathrm{L}$ dan $15 \mathrm{cc} / \mathrm{L}$. Hasil penelitian Purwaningsih dan Rahmansyah (1993) menunjukkan bahwa tanaman kedelai yang diinokulasi dengan biak Rhizobium, Mikoriza dan gabu- 
ngan keduanya umumnya mampu meningkatkan bobot kering tajuk, bintil, jumlah bintil, dan polong. Kenaikan berkisar 1,16 hingga 172,54\% bila Vegetalika 2(2), 20139 dibandingkan dengan tanaman tanpa diinokulasi.

Untuk derajat infeksi akar tertinggi terdapat pada perlakuan $15 \mathrm{~g} /$ polybag, sedangkan perlakuan PPC tidak memberikan pengaruh yang nyata terhadap derajat infeksi akar, sedangkan untuk bobot kering per tanaman, perlakuan MVA tidak memberikan pengaruh, sedangkan untuk PPC adalah pada perlakuan 20 cc/L.

Tabel 3. Pengaruh Inokulasi Mikoriza Vesikular Arbuskula (MVA) dan Pupuk Pelengkap Cair terhadap Nodul Akar Efektif , Derajat Infeksi akar dan Bobot Kering per tanaman.

\begin{tabular}{lccc}
\hline \hline Perlakuan & $\begin{array}{c}\text { Nodul } \\
\text { Akar } \\
\text { Efektif }\end{array}$ & $\begin{array}{c}\text { Derajat } \\
\text { Infeksi } \\
\text { Akar }(\%)\end{array}$ & $\begin{array}{c}\text { Bobot } \\
\text { Kering } \\
(\mathrm{g})\end{array}$ \\
\hline MVA (M) & & & \\
$\mathrm{m}_{1}$ & $57.33 \mathrm{a}$ & $26.42 \mathrm{a}$ & $81.93 \mathrm{a}$ \\
$\mathrm{m}_{2}$ & $40.67 \mathrm{ab}$ & $25.66 \mathrm{a}$ & $78.30 \mathrm{a}$ \\
$\mathrm{m}_{3}$ & $28.01 \mathrm{~b}$ & $28.67 \mathrm{~b}$ & $74.87 \mathrm{a}$ \\
PPC (P) & & & \\
$\mathrm{p}_{1}$ & $31.67 \mathrm{a}$ & $27.46 \mathrm{a}$ & $74.55 \mathrm{a}$ \\
$\mathrm{p}_{2}$ & $37.33 \mathrm{a}$ & $28.45 \mathrm{a}$ & $75.70 \mathrm{a}$ \\
$\mathrm{p}_{3}$ & $57.02 \mathrm{~b}$ & $26.48 \mathrm{a}$ & $84.85 \mathrm{~b}$ \\
\hline \hline
\end{tabular}

Keterangan : Nilai rata-rata perlakuan yang ditandai huruf yang sama pada kolom yang sama menunjukkan tidak berbeda nyata menurut Uji Jarak Berganda Duncan pada taraf $5 \%$.

Hasil penelitian Muis et al. (2013) menunjukkan bahwa pemberian mikoriza tidak meningkatkan bobot kering total umur 8 MST, panjang akar total, luas permukaan akar dan volume akar pada kedelai varietas Wilis yang ditanam dengan interval penyiraman yang berbeda.

Jumlah Polong Isi dan Jumlah Polong Hampa per Tanaman. Berdasarkan analisis data statistik, jumlah polong isi dan jumlah polong hampa, dan data pada Tabel 3, perlakuan MVA dan pupuk pelengkap cair tidak memberikan pengaruh interaksi terhadap jumlah polong isi dan polong hampa. Secara mandiri, jumlah polong isi terbaik terdapat pada perlakuan 5 $\mathrm{g} /$ polybag MVA bila dibandingkan dengan $10 \mathrm{~g}$ dan $15 \mathrm{~g} /$ polybag. Untuk jumlah polong hampa, MVA tidak memberikan pengaruh nyata, sedangkan pada perlakuan PPC $10 \mathrm{cc} /$ polybag, jumlah polong hampanya paling sedikit.
Tabel 3. Pengaruh Inokulasi Mikoriza Vesikular Arbuskula (MVA) dan Pupuk Pelengkap Cair terhadap Jumlah Polong Isi dan Jumlah Polong Hampa per Tanaman.

\begin{tabular}{lcc}
\hline \multicolumn{1}{c}{ Perlakuan } & $\begin{array}{c}\text { Jumlah } \\
\text { Polong Isi }\end{array}$ & $\begin{array}{c}\text { Jumlah Polong } \\
\text { Hampa }\end{array}$ \\
\hline MVA (M) & & \\
$\mathrm{m}_{1}$ & $28.28 \mathrm{a}$ & $5.23 \mathrm{a}$ \\
$\mathrm{m}_{2}$ & $23.73 \mathrm{~b}$ & $4.12 \mathrm{a}$ \\
$\mathrm{m}_{3}$ & $22.51 \mathrm{~b}$ & $4.55 \mathrm{a}$ \\
PPC (P) & & \\
$\mathrm{p}_{1}$ & $24.62 \mathrm{a}$ & $3.65 \mathrm{a}$ \\
$\mathrm{p}_{2}$ & $24.22 \mathrm{a}$ & $3.42 \mathrm{a}$ \\
$\mathrm{p}_{3}$ & $23.68 \mathrm{a}$ & $4.68 \mathrm{~b}$ \\
\hline \hline
\end{tabular}

Keterangan : Nilai rata-rata perlakuan yang ditandai huruf yang sama pada kolom yang sama menunjukkan tidak berbeda nyata menurut Uji Jarak Berganda Duncan pada taraf $5 \%$.

Bobot 100 butir, Bobot Biji per Tanaman dan Indeks Panen. Berdasarkan analisis data statistik, perlakuan MVA dan pupuk pelengkap cair tidak memberikan pengaruh interaksi terhadap bobot 100 butir, bobot biji per tanaman dan indeks panen. Secara mandiri, bobot 100 butir, tidak memberikan pengaruh yang nyata, sedangkan bobot biji per tanaman dan indeks panen memberikan pengaruh yang nyata.

Untuk bobot biji per tanaman, perlakuan MVA $10 \mathrm{~g} /$ polybag dan $15 \mathrm{~g} /$ polybag (Tabel 4) memberikan pengaruh yang lebih baik dibandingkan dengan perlakuan MVA $5 \mathrm{~g} /$ polybag. Untuk PPC, perlakuan $20 \mathrm{cc} / \mathrm{L}$ memberikan pengaruh yang lebih baik dibandingkan dengan $10 \mathrm{cc} / \mathrm{L}$ dan $15 \mathrm{cc} / \mathrm{L}$.

Tabel 4. Pengaruh Inokulasi Mikoriza Vesikular Arbuskula (MVA) dan Pupuk Pelengkap Cair terhadap bobot 100 butir, bobot biji per tanaman dan indeks panen

\begin{tabular}{lccc}
\hline \hline Perlakuan & $\begin{array}{c}\text { Bobot 100 } \\
\text { butir }(\mathrm{g})\end{array}$ & $\begin{array}{c}\text { Bobot Biji } \\
\text { per } \\
\text { Tanaman }(\mathrm{g})\end{array}$ & $\begin{array}{c}\text { Indeks } \\
\text { Panen }\end{array}$ \\
\hline MVA (M) & & & \\
$\mathrm{m}_{1}$ & $10.38 \mathrm{a}$ & $31.71 \mathrm{a}$ & $0.42 \mathrm{a}$ \\
$\mathrm{m}_{2}$ & $10.91 \mathrm{a}$ & $27.82 \mathrm{~b}$ & $0.38 \mathrm{~b}$ \\
$\mathrm{~m}_{3}$ & $10.28 \mathrm{a}$ & $25.17 \mathrm{~b}$ & $0.39 \mathrm{~b}$ \\
PPC $(\mathrm{P})$ & & & \\
$\mathrm{p}_{1}$ & $10.82 \mathrm{a}$ & $26.21 \mathrm{a}$ & $0.35 \mathrm{a}$ \\
$\mathrm{p}_{2}$ & $10.43 \mathrm{a}$ & $26.42 \mathrm{a}$ & $0.36 \mathrm{a}$ \\
$\mathrm{p}_{3}$ & $10.33 \mathrm{a}$ & $28.46 \mathrm{~b}$ & $0.40 \mathrm{~b}$ \\
\hline \hline
\end{tabular}

Keterangan : Nilai rata-rata perlakuan yang ditandai huruf yang sama pada kolom yang sama menunjukkan tidak berbeda nyata menurut Uji Jarak Berganda Duncan pada taraf $5 \%$. 
Menurut penelitian Proborini (2011) bahwa tanaman yang berfotosintesis dengan aktif akan memberikan pengaruh yang positif terhadap penambahan jumlah daun, berat tanaman, berat akar, dan tajuk, sehingga tanaman yang bermikoriza akan memiliki jumlah daun dan bobot tanaman yang lebih tinggi dibandingkan dengan tanpa MVA.

\section{Kesimpulan dan Saran}

Berdasarkan hasil percobaan dapat disimpulkan sebagai berikut:

1. Perlakuan MVA dan pupuk pelengkap cair (PPC) tidak memberikan pengaruh interaksi terhadap tinggi tanaman, indeks luas daun, jumlah cabang produktif dan jumlah buku subur, jumlah polong isi dan jumlah polong hampa per tanaman, bobot 100 butir, bobot biji per tanaman dan indeks panen.

2. Secara mandiri, perlakuan $5 \mathrm{~g} /$ polybag MVA dan perlakuan $20 \mathrm{cc} / \mathrm{L}$ pupuk pelengkap cair, memberikan pengaruh yang lebih baik terhadap tinggi tanaman, indeks luas daun, jumlah cabang produktif dan jumlah buku subur, jumlah polong isi dan jumlah polong hampa per tanaman, bobot 100 butir, bobot biji per tanaman dan indeks panen.

Saran pada percobaan ini adalah penggunaan pupuk pelengkap cair dengan konsentrasi yang lebih tinggi yang diberikan melalui daun, dan dosis MVA lebih dari 5 g/polybag.

\section{Ucapan Terima Kasih}

1. Kepala Kebun dan Rumah Kaca Fakultas Pertanian Universitas Padjadjaran.

2. Mahasiswa Peminatan Pangan Departemen Budidaya Pertanian Fakultas Pertanian Universitas Padjadjaran.

\section{Daftar Pustaka}

Bethlenfalvay, G. J., M.G. Reyes-Solis, S.B. Camel and R. Ferrera-Cerrato. 1991. Nutrient transfer between The root Zones of soybean and maize plants. Connected by a Common
Mycorrhizal Mycelium. Physiol. Plant 82, 423-432.

Biro Pusat Statistik. 2015. Luas Lahan Kedelai di Indonesia. Jakarta.

Brundrett, M. N. Bougher, B Dell. T. Grove and N. Malajczuk. 1996. Working with Mycorrhizas in Forestry and Agriculture. ACIAR Monograph 32:374p.

Darmawijaya, 1992. Budidaya tanaman Kacangkacangan. Bina Aksara, Jakarta.

Harley, J. L. and M. S. Smith. 1983. Mycorrhizal Syimbiosis. Academic Press, Inc. New York. 483 p.

Muis, A., D. Indradewa dan J. Widada. Pengeruh Inokulasi Mikoriza terhadap Pertumbuhan dan hasil Kedelai (Glycine $\max ($ L.) Merrill) pada Berbagai Interval Penyiraman. Vegetalika, 2(2): 7-20

Oldeman, L.R., 1975. Agroclimatic map of Java and Madura. Contr. of Centra Res. Inst. for Food Crops 16/76. Bogor.

Proborini, M. W. 2011. Eksplorasi jenis-jenis endomikoriza indigenus pada lahan kering di Bali dan Pemanfaatannya. Laporan Hibah Doktor. Dana DIPA Universitas Udayana No.079- 042-01/20/2011. Denpasar. Bali.

Purwaningsih, S. dan M. Rahmansyah. 1993. Upaya pemanfaatan inokulan rhizobium dan jamur MVA pada kedelai dan kacang tanah. Pros. Seminar Hasil Litbang SDH 14 Juni 1993 hal. 413-418.

Schinner et al., 1996. An evaluation of techniques for measuring vesicular arbuscular mycorrhizal infection in roots. New Phytol. 84:489-500.

Setiadi Y. 2003. Arbuscular Mycorrhizal Inoculum Production. Program dan Abstrak Seminar dan Pameran. Teknologi Produksi dan Pemanfaatan Inokulan Endo-ektomikoriza untuk pertanian, perkebunan dan kehutanan. 16 Sept. 2003. Bandung. p.10.

Sharma et al., 2004. Nutrien Uptake in Mycorrhiza activities, J. Plant and Soil. $158: 72$.

Sumarno. 1987. Kedelai dan Teknik Budidayanya. Balai Penelitian Tanaman Bogor.

Sumarno. 2011. Perkembangan Teknologi Budidaya Kedelai di Lahan Sawah. Iptek Tanaman Pangan 6 (2): 139-151.

Taiz dan Zeiger (2002. An apparent increase in symplasmic in water contributes to greater turgor in mycoffhizal roots of droughted Rice Plant. New Phytol. 115, 285-295. 